http://journal.uinsgd.ac.id/index.php/biodjati

\title{
ODONATA DIVERSITY AT SUMBER CLANGAP AND SUMBER MANGLI PUNCU VILLAGE SUB DISTRICT OF PUNCU DISTRICT OF KEDIRI
}

\author{
Muhibbuddin Abdillah*1, Tatag Bagus Putra Prakarsa², Esti Tyastirin ${ }^{3}$
}

Received : June 09, 2019

Accepted : September 26, 2019

DOI: 10.15575/biodjati.v4i2.4823

1, 3 Biology Department, Faculty of Science and Technology UIN Sunan Ampel, Jl. Ahmad Yani No.117, Jemur Wonosari, Kec. Wonocolo, Surabaya, East Java, Indonesia 60237

${ }^{2}$ Biology Department, Universitas Negeri Yogyakarta, Jl. Colombo No.1, Karang Malang, Caturtunggal, Daerah Istimewa Yogyakarta, Indonesia 55281

e-mail:

*1abdillah.kutrik@gmail.com

²bagusprakarsa13@gmail.com

3esty50@gmail.com

*Corresponding author

\begin{abstract}
Sumber Clangap and Sumber Mangli are geographically located at the Mount Kelud steeps. Administratively located at Puncu Village, Puncu Sub-district and District of Kediri. They provided habitat for the flora than fauna especially Odonata that never been studied before. We aimed to study Odonata diversity at Sumber Clangap and Sumber Mangli area. The method used in this study was natural snapshot experiment that conducted by Odonata monitoring. Microclimate parameter including air temperature and humidity were noted. Odonata activity and behavior noted for analysis. Collected data were analyzed using Shannon-Wiener heterogeneity index. The results showed that there were 17 species from the whole location. There was Euphaea variegata, Vestalis luctuosa, Rhinocypha anisoptera, Pericnemis stictica, Pseudagrion pruinosum, Coeliccia membranipes, Gynacantha subinterrupta, Idionyx montana, Paragomphus reinwardtii, Heliogomphus drescheri, Neurothemis fluctuans, Orthetrum glaucum, Orthetrum pruinosum, Orthetrum sabina, Pantala flavescens, Trithemis festiva and Zygonyx ida. Based on the Shannon-Wiener heterogeneity index the value, Sumber Clangap had heterogeneity index higher $\left(H^{\prime}=1,97\right)$ than Sumber Mangli $\left(H^{\prime}=1,39\right)$. Sumber Mangli has a Java endemic species Paragomphus reinwardtii and Rhinocypha anisoptera that is spread only at Sumatera and East Java.
\end{abstract}

Keywords: Sumber Clangap, Sumber Mangli, Odonata diversity

\section{Citation}

Abdillah, M., Prakarsa, T. B. P. \& Tyastirin, E. (2019). Odonata Diversity at Sumber Clangap and Sumber Mangli Puncu Village Sub District of Puncu District of Kediri. Jurnal Biodjati, 4(2), 236243

\section{INTRODUCTION}

Sumber Clangap and Mangli are water springs located at Puncu Village, Puncu Sub-district and District of Kediri. They are clean water source used by the villagers of Pun$\mathrm{cu}$ Sub district including Puncu, Asmorobangun, Satak and Kampungbaru villagers.

Sumber Clangap and Sumber Mangli stream also providing water for the ri- parian vegetation that forms a forest. The forests are managed by State Forest Enterprise (Perum Perhutani). Mount Kelud eruption in 2014 had a great impact on Sumber Clangap streams. However, Sumber Mangli safe from the eruption in 2014 and this water spring still provide clean water while the crisis. Based on those reasons, Sumber Clangap and Sumber Mangli have a potential to be habitat for undescribed species 


\section{JURNAL BIDDJATI}

http://journal.uinsgd.ac.id/index.php/biodjati

Odonata has predicted consist of 1.989 species and more than 1.499 are well described. Among described Odonata, 123 $(8 \%)$ from them has threatened, 63 (4\%) has near threatened, 527 (35\%) have data deficiency and $786(53 \%)$ are the least concern (IUCN, 2009). In Indonesia, the study about Odonata has not been conducted for a whole location. Studies about Odonata are limited only at of each island or region.

Studies about biodiversity especially Odonata in Java Island have been conducted only in some region. Odonata diversity at Yogyakarta are 71 species (Setiyono et al., 2017), Magetan District found 19 species (Pamungkas \& Ridwan, 2015), and Telaga Wendit Malang District found 36 species (Rahadi et al., 2013). Based on Lieftinck (1934) there are 142 species spreads at Java. Setiyono (2014), noted 88 species from some regions at Java. Based on the mentioned statement about the Odonata data we aimed to study Odona- ta Diversity at Sumber Clangap and Sumber Mangli. The latest data about Javan Odonata was not clear thus the update urgently needed.

\section{MATERIALS AND METHODS}

\section{Study Location}

This study was conducted at Sumber Clangap and Sumber Mangli where both location are the watersprings. Observation was carried out in five plots of each location (Figure 1).

\section{Specimen Collection and Identification}

Specimen collected by Natural Snapshot Experimental Studies (NSEs) (Case \& Diamond, 1986). Specimen randomly collected in each monitoring plots (Simple Random Sampling) (Krebs, 1989). Specimen collected ideally in 08:00-15:00 local time based on the Odonata active hour. Collected specimens were identified using field guide (Borror et al., 1989; Orr, 2004 \& Setiyono et al., 2017).

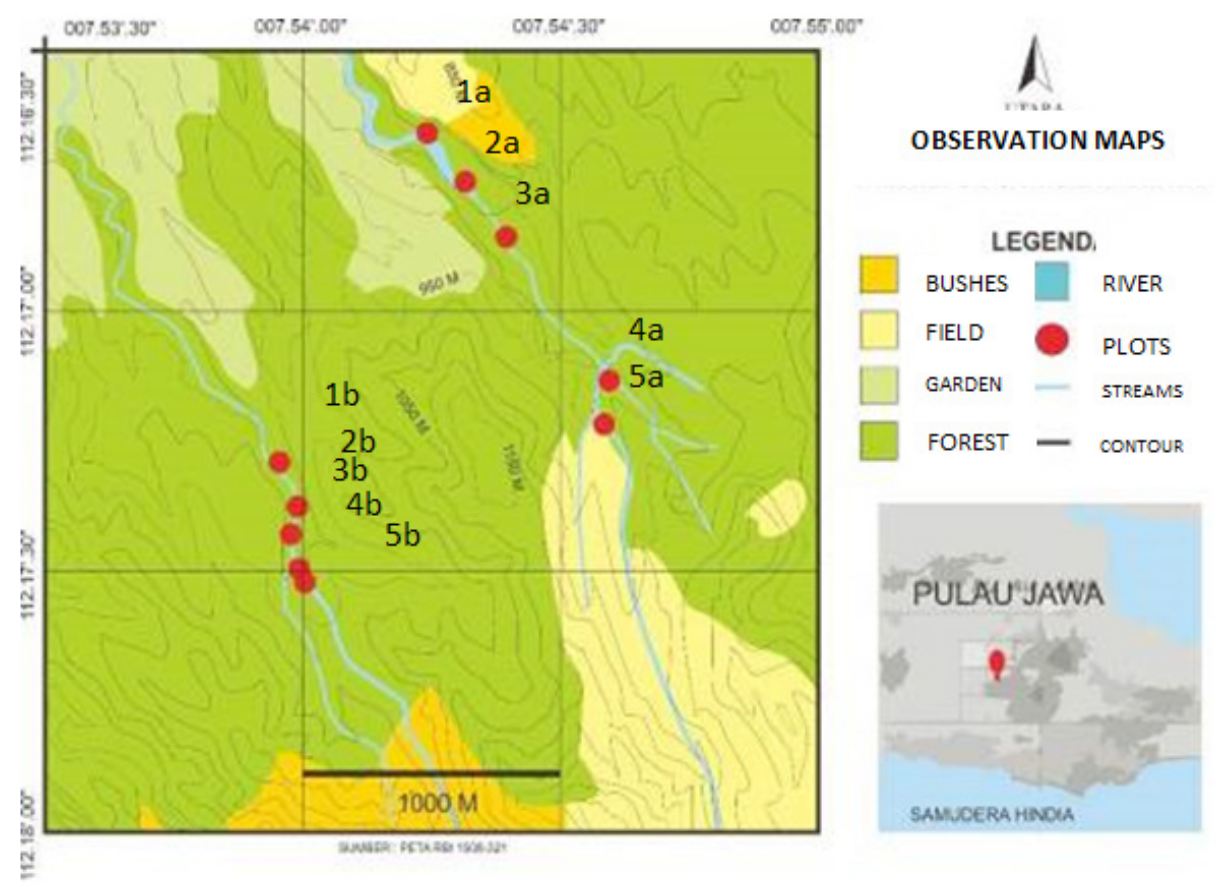

Figure 1. Study Location Maps (1a-5a Sumber Clangap, 1b-5b Sumber Mangli) 


\section{JURNAL BIDDJATI}

http://journal.uinsgd.ac.id/index.php/biodjati

\section{Data Analysis}

Collected Odonata specimens were identified then summed according to its species. Collected data were then analyzed using the Shannon-Wiener heterogeneity index for measuring diversity level from each study location with the following formula Jorgensen et al. (2010) and Krebs (1989):

$$
H^{\prime}=-\sum p_{i} \ln p_{i}
$$

Notes:

$H^{\prime}=$ Shannon-Wiener Heterogeneity Index

$p_{i}=$ ratio of $N_{i} / N$

$N_{i}=$ amount of individual species i

$N$ = amount of individual

\section{Microclimate and Behavior Observation}

Microclimate parameter observed were air temperature and humidity. Air temperature and humidity data were taken using digital thermohygrometer. Microclimate parameter of each observation plot were calculated for the further analysis.

Odonata activity and behavior were noted for the analysis. The Activities observed including perching, hunting, mating, ovipositing and fight for territorial. Each activity factor noted to each species for different time period.

\section{RESULTS AND DISCUSSION}

Sumber Clangap had a heterogeneity value of 1.97 with the dominant species from Suborder of Anisoptera while Sumber Mangli had a diversity value of 1.39 with the dominant species from Sub ordo of Zygoptera (Figure 2). Shannon-Wiener heterogeneity index and Simpson index generally used for measuring diversity level in a population (Hill et al., 2005).

Diversity (heterogeneity) level may differ based on some factors for example habi- tat, territoriality and physical condition of the environment. The dominant factors that play a role are the natural resource, preys, habitat and species flight ability (Herlambang et al., 2016). Some of Anisoptera species are liable to have high flight ability. Flight ability is influenced by wings aerodynamic and habitat (Johnson, 1969).

Preys availability in each study location very influenced by the organics material which goes into the water. Water spring ecosystem does not have its own organic material until there is organics material pollution (Odum, 1989). Different villager's activities also affected both study locations. Sumber Clangap with high villagers' activities brings organic material pollution into the water bodies. The pollution provides a natural resource for the Odonata naiads preys then affected to the population diversity value.

The heterogeneity index on each monitoring month had a different value. Sumber Clangap had a heterogeneity index that more fluctuated on each month. It may be affected by the different imago phases from each species. Almost every Odonata species molted at the beginning of the rainy season on January. Diversity fluctuation of each month is very influenced by canopy amount and geographic isolation. A trees canopy and geographic isolation affected the air temperature and humidity that influenced Odonata life cycle (Corbet, 1962).

Unlike Sumber Clangap, Odonata diversity index more stable of each monitoring month in Sumber Mangli. The index affected by the geographic isolation of Sumber Mangli where located between narrow cliffs and thick canopies. This condition made the microclimate more stable including air temperature, air humidity and water streams to this location (Figure 3). Sumber Clangap air temperature and humidity significantly more fluctuated 


\section{JURNAL BIDDJATI}

http://journal.uinsgd.ac.id/index.php/biodjati

than Sumber Mangli.

The air temperature on Sumber Clangap was averagely lower than Sumber Mangli. The average temperature was not significantly different because the measuring times were different. Sunlight intensity increased during the day influence the air temperature. The narrow cliffs and thick canopies at Sumber Clangap inhibit the air temperature rate.

Microclimate and vegetation play the role to provide habitat for the small insects.
The small insects from the other species are prey to the Odonata. Main preys of the Odonata are mosquitos, small moth and the other smaller Odonata species (Setiyono, 2017). Libellulidae hunt around bush and herbs vegetation to prey and hide from their predators on trees (Abdillah et al., 2018). Libellulidae only found at Sumber Clangap but absent at Sumber Mangli due to microclimate adaptation and different on vegetation composition.

\section{Shannon-Wiener Heterogeneity Index}

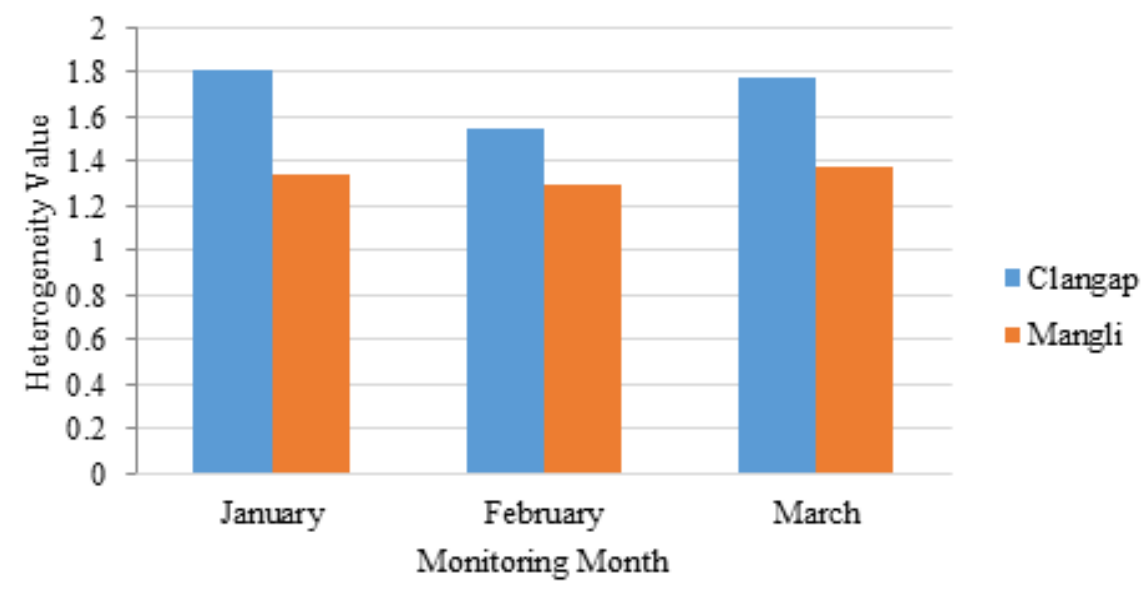

Figure 2. Shannon-Wiener Heterogeneity Index Analysis Results

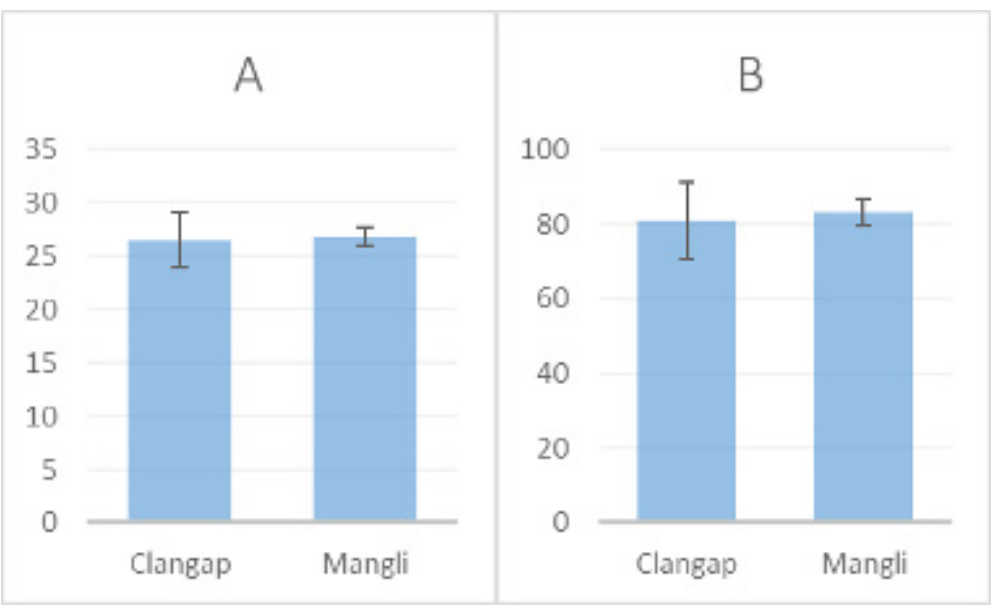

Figure 3. (A) Air temperature during monitoring $\left({ }^{\circ} \mathrm{C}\right)$, (B) Relative air humidity during monitoring $(\%)$ 
Jurnal Biodjati 4(2):236-243, November 2019

\section{JURNAL BIDDJATI}

http://journal.uinsgd.ac.id/index.php/biodjati

Table 1. The list of species found in Sumber Clangap and Sumber Mangli

\begin{tabular}{|c|c|c|c|}
\hline \multirow{2}{*}{ Family } & \multirow{2}{*}{ Species } & \multicolumn{2}{|c|}{ Number } \\
\hline & & Clangap & Mangli \\
\hline Euphaeaidae & Euphaea variegata & 91 & 93 \\
\hline Calopterygidae & Vestalis luctuosa & 151 & 174 \\
\hline Clorocyphidae & Rhinocypha anisoptera & - & 59 \\
\hline \multirow[t]{2}{*}{ Coenagrionidae } & Pericnemis stictica & 1 & 2 \\
\hline & Pseudagrion pruinosum & 4 & - \\
\hline Platycnemididae & Coeliccia membranipes & 8 & 17 \\
\hline Aeshnidae & Gynacantha subinterrupta & - & 1 \\
\hline Cordulidae & Idionyx montana & - & 2 \\
\hline \multirow[t]{2}{*}{ Gomphidae } & Paragomphus reinwardtii & - & 1 \\
\hline & Heliogomphus drescheri & 3 & - \\
\hline \multirow[t]{8}{*}{ Libellulidae } & Neurothemis fluctuans & 2 & 2 \\
\hline & Orthetrum glaucum & 59 & 1 \\
\hline & Orthetrum pruinosum & 9 & 3 \\
\hline & Orthetrum sabina & 22 & - \\
\hline & Pantala flavescens & 86 & - \\
\hline & Trithemis festiva & 85 & - \\
\hline & Zygonyx ida & 24 & 7 \\
\hline & TOTAL & 545 & 362 \\
\hline
\end{tabular}

Euphaea variegata and Vestalis luctuo$s a$ habitat are identic so they often found at the same location (Lieftinck, 1934). Pericnemis stictica found in both locations indicate that both study locations are identic on some aspect. Pericnemis stictica lays their eggs at phytotelmata that made from bamboos that found on both locations (Setiyono et al., 2017). Heavy and clear forest water streams support the Zygonyx ida habitat requirements also indicate that both of location provide same forest habitat (Orr, 2005).

Odonata that found at Sumber Clangap but not at Sumber Mangli indicated that the species has different needs on sunlight. Some species like Pseudagrion pruinosum, Orthetrum sabina, Pantala flavescens and Trithemis festiva only found at Sumber Clangap that have more sunlight intensity than Sumber Mangli. The sunlight influences the Odonata behavior including hunt and egg laying activity (Corbet, 1962). Orthetrum glaucum and Orthetrum pruinosum found more often at Sumber Clangap might be due to the sunlight intensity that more suitable for them. The sunlight intensity is suitable for their behavior that likes to perch on a riparian that not covered by the canopies during the day. Coeliccia membranipes found more often at Sumber Mangli might be due to its behavior that likes to perch on leaf tip that covered by thick canopies. Neurothemis fluctuans are able to fly far from the water bodies so its presence did not effected by sunlight intensity. Neurothemis fluctuans like to lay their eggs on a pond but their territory until the forest (Orr, 2006).

The Odonata species presence is very influenced by the sunlight intensity on its habitat. Trees present to provide the canopies that influenced by sunlight intensity on their below environment. Sunlight intensity is not 


\section{JURNAL BIDDJATI}

http://journal.uinsgd.ac.id/index.php/biodjati

just affected the Odonata behavior but also its wings pigmentation. Color pigmentation correlated with temperature adaptation and mate behavior of Odonata (Svenson \& Waller, 2013). Darker wings color found more often in species that live in habitat below thick canopies. Thick canopies decrease the relative temperature, while the dark wings need to adsorb more calories from the environment.

The difference of species distribution in each monitoring plots also affected by the canopy thickness difference. Libellulidae members need heavy sunlight intensity for their activities. All the monitoring plots at Sumber Clangap had low canopy thicknesses untill the Libellulidae found there. Libellulidae members also found in $1 \mathrm{~B}$ and $5 \mathrm{~B}$ plots at Sumber Mangli because its plots have a high sunlight intensity.
Based on the study results, there was 17 Odonata species live at Sumber Clangap and Sumber Mangli. The species are Euphaea variegata, Vestalis luctuosa, Rhinocypha anisoptera, Pericnemis stictica, Pseudagrion pruinosum, Coeliccia membranipes, Gynacantha subinterrupta, Idionyx montana, Paragomphus reinwardtii, Heliogomphus drescheri, Neurothemis fluctuans, Orthetrum glaucum, Orthetrum pruinosum, Orthetrum sabina, Pantala flavescens, Trithemis festiva and Zygonyx ida. Based on the Shannon-Wiener heterogeneity index the value of Sumber Clangap is higher $\left(H^{\prime}=1,97\right)$ than Sumber Mangli $\left(H^{\prime}=1,39\right)$. Endemic species Paragomphus reinwardtii and Rhinocypha anisoptera that is spread only at Sumatera and East Java found at Sumber Mangli.

Table 2. Species Presence at Sumber Clangap and Sumber Mangli

\begin{tabular}{|c|c|c|c|c|c|c|c|c|c|c|}
\hline \multirow{2}{*}{ Species } & \multicolumn{10}{|c|}{ Presence } \\
\hline & $1 \mathrm{~A}$ & $2 \mathrm{~A}$ & $3 \mathrm{~A}$ & $4 \mathrm{~A}$ & $5 \mathrm{~A}$ & $1 \mathrm{~B}$ & $2 \mathrm{~B}$ & $3 B$ & $4 \mathrm{~B}$ & $5 \mathrm{~B}$ \\
\hline Euphaea variegata & $\sqrt{ }$ & $\sqrt{ }$ & $\sqrt{ }$ & $\sqrt{ }$ & $\sqrt{ }$ & $\sqrt{ }$ & $\sqrt{ }$ & $\sqrt{ }$ & $\sqrt{ }$ & $\sqrt{ }$ \\
\hline Vestalis luctuosa & $\sqrt{ }$ & $\sqrt{ }$ & $\sqrt{ }$ & $\sqrt{ }$ & $\sqrt{ }$ & $\sqrt{ }$ & $\sqrt{ }$ & $\sqrt{ }$ & $\sqrt{ }$ & $\sqrt{ }$ \\
\hline Rhinocypha anisoptera & - & - & - & - & - & $\sqrt{ }$ & $\sqrt{ }$ & $\sqrt{ }$ & $\sqrt{ }$ & $\sqrt{ }$ \\
\hline Pericnemis stictica & - & - & - & $\sqrt{ }$ & - & $\sqrt{ }$ & - & - & - & - \\
\hline Pseudagrion pruinosum & $\sqrt{ }$ & - & - & - & - & - & - & - & - & - \\
\hline Coeliccia membranipes & $\sqrt{ }$ & - & $\sqrt{ }$ & $\sqrt{ }$ & - & $\sqrt{ }$ & $\sqrt{ }$ & - & $\sqrt{ }$ & $\sqrt{ }$ \\
\hline Gynacantha subinterrupta & - & - & - & - & - & $\sqrt{ }$ & - & - & - & - \\
\hline Idionyx montana & - & - & - & - & - & $\sqrt{ }$ & - & - & - & - \\
\hline Paragomphus reinwardtii & - & - & - & - & - & $\sqrt{ }$ & - & - & - & - \\
\hline Heliogomphus drescheri & - & - & - & - & $\sqrt{ }$ & - & - & - & - & - \\
\hline Neurothemis fluctuans & $\sqrt{ }$ & - & - & - & - & $\sqrt{ }$ & $\sqrt{ }$ & - & - & - \\
\hline Orthetrum glaucum & $\sqrt{ }$ & $\sqrt{ }$ & $\sqrt{ }$ & $\sqrt{ }$ & $\sqrt{ }$ & $\sqrt{ }$ & - & - & - & - \\
\hline Orthetrum pruinosum & $\sqrt{ }$ & - & - & - & $\sqrt{ }$ & $\sqrt{ }$ & - & - & - & $\sqrt{ }$ \\
\hline Orthetrum sabina & $\sqrt{ }$ & $\sqrt{ }$ & $\sqrt{ }$ & $\sqrt{ }$ & - & - & - & - & - & - \\
\hline Pantala flavescens & $\sqrt{ }$ & $\sqrt{ }$ & $\sqrt{ }$ & $\sqrt{ }$ & $\sqrt{ }$ & - & - & - & - & - \\
\hline Trithemis festiva & $\sqrt{ }$ & $\sqrt{ }$ & $\sqrt{ }$ & $\sqrt{ }$ & $\sqrt{ }$ & - & - & - & - & - \\
\hline Zygonyx ida & $\sqrt{ }$ & - & - & - & $\sqrt{ }$ & $\sqrt{ }$ & - & - & $\sqrt{ }$ & $\sqrt{ }$ \\
\hline
\end{tabular}

Note: 1A-5A Sumber Clangap, 1B-5B Sumber Mangli 
Jurnal Biodjati 4(2):236-243, November 2019

\section{JURNAL BI@DJATI}

http://journal.uinsgd.ac.id/index.php/biodjati
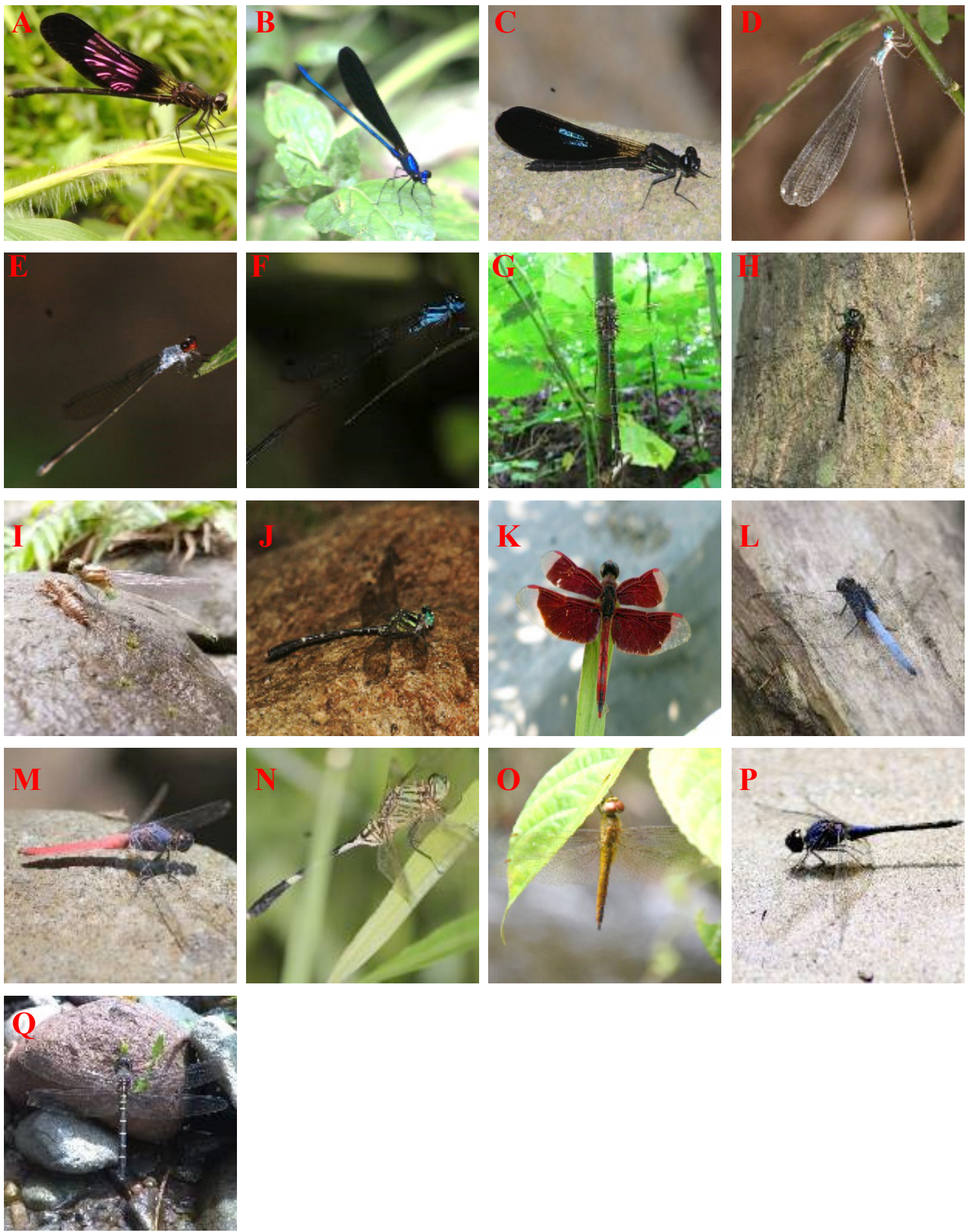

Figure 4. (A) Euphaea variegata, (B) Vestalis luctuosa, (C) Rhinocypha anisoptera, (D) Pericnemis stictica, (E) Pseudagrion pruinosum, (F) Coeliccia membranipes, (G) Gynacantha subinterrupta, (H) Idionyx montana, (I) Paragomphus reinwardtii, (J) Heliogomphus drescheri, (K) Neurothemis fluctuans, (L) Orthetrum glaucum, (M) Orthetrum glaucum, (N) Orthetrum sabina, (O) Pantala flavescens, (P) Trithemis festiva, (Q) Zygonyx ida (Muhibbuddin Abdillah@, Arif Rahman(), Fathurrahman Sidiq $($, Widya Pertiwi( ) 


\section{JURNAL BIDDJATI}

http://journal.uinsgd.ac.id/index.php/biodjati

\section{ACKNOWLEDGMENTS}

This study was supported by RPH Besowo East Java State Forest Enterprise (Perum Perhutani), KUTRIK Entomology Study Club, Himpunan Mahasiswa Biologi UIN Sunan Ampel (HIMABISA) and Puncu Villagers. Thanks to Widya Pertiwi, Najmatul Millah and Nauval Arroyyan, Tri Jayanti, Firdaus Alifuddin, Aziz Qoharuddin and Arif Rahman as crew and contributors.

\section{REFERENCES}

Abdillah, M. Millah, N. Arroyyan, N. Alifuddin, F. \& W. Pertiwi. 2019. Correlation Between Libellulidae Diversity and Vegetation Diversity at Sumber Clangap Village of Puncu, Sub district of Puncu, District of Kediri. International Symposium on Bioremediation and Revegetation Technologies Proceeding 2018.

Borror, D. J., Triplehorn, C. A. \& Johnson, N. F. (1989). An Introduction to the Study of Insects (No. Ed. 6). Saunders college publishing.

Corbet,P.S.(1962).BiologyofOdonata.Annual Review of Entomology, 25(1), 189-217.

Herlambang, A. E. N., Hadi, M. \& Tarwotjo, U. (2016). Struktur Komunitas Capung di Kawasan Wisata Curug Lawe Benowo Ungaran Barat. Bioma: Berkala Ilmiah Biologi, 18(2), 70-78.

Hill, D. Fasham, M. Tucker, G., Shewry M. \& Shaw, P. (2005). Handbook of Biodiversity Method: Survey, Evaluation Ana Monitoring. Cambridge University Press, New York.

IUCN. (2009). The IUCN Red List of Threatened Species ${ }^{\mathrm{TM}} 2009$ update: Odonata Facts. Red list IUCN. Accessed on 22 August 2017 in https://www.iucn.org/ downloads/more_facts_on_odonata.pdf
Johnson, C. G. (1969). Migration and Dispersal of Insects by Flight. Methuen And Co. Ltd., London.

Jorgensen, S. E., F. Xu, R. \& Constanta. (2010). Ecological Indicators for Assessment of Ecosystem Health. Copenhagen University, Denmark.

Krebs, C. J. (1989). Ecological Methodology. Harper \& Row, New York.

Lieftinck, M. A. (1934). An Annotated List of the Odonata of Java, With Notes on Their Distribution, Habits and Life-History. Treubia, 14(4), 377-462

Odum, E. P., Odum, H. T. \& Andrews, J. (1971). Fundamentals of ecology (Vol. 3). Philadelphia: Saunders.

Orr, A. G. (2005). Dragonflies of Peninsular Malaysia and Singapore. Natural History Publication. Kota Kinabalu

Pamungkas, D. W. \& Ridwan, M. (2015). Keragaman Jenis Capung dan Capung Jarum (Odonata) di Beberapa Sumber Air di Magetan, Jawa Timur. In Prosiding Seminar Nasional Masyarakat Biodiversitas Indonesia Vol. 1, pp. 1295-1301.

Rahadi, W. S., Feriwibisono, B., Nugrahani, M. P., Dalia, B. P. I. \& Makitan, T. (2013). Naga Terbang Wendit: Keanekaragaman Capung Perairan Wendit, Malang, Jawa Timur. Indonesia Dragonfly Society.

Setiyono, J. (2014). Java Odonata Survey. Agrion, 18(2).

Setiyono, J., S. Diniarsih, E. Nur Respatika \& N. Setio Budi. (2017). Dragonflies of Yogyakarta. Indonesian Dragonflies Society, Yogyakarta.

Svensson, E. I. \& Waller, J. T. (2013). Ecology and Sexual Selection: Evolution of Wing Pigmentation in Calopterygid Damselflies in Relation to Latitude, Sexual Dimorphism, and Speciation. The American Naturalist, 182(5), 174-195. 